\title{
The Case Against a Nondelegable Duty on Owners to Prevent Fair Housing Act Violations
}

\author{
Joshua W. Dixon $\dagger$
}

Imagine that the owner of a residential investment property hires a broker to find tenants for the property. The owner specifically instructs the broker not to discriminate in the selection of tenants, and takes affirmative steps to ensure that the broker does not do so. Without the owner's knowledge, the broker discriminates while selecting tenants. Should the owner be liable as a matter of law for the compensatory damages caused by the broker's discrimination? This Comment argues that the owner should not. ${ }^{2}$

The Fair Housing Act ("FHA," "Act," or "Title VIII") creates a federal cause of action for discrimination in housing. Courts generally apply traditional principles of agency law ${ }^{4}$ to determine whether the owners of a property (or the owners of a brokerage firm ${ }^{5}$ ) are liable

\footnotetext{
$\dagger$ B.A. 1995, Wake Forest University; J.D. 2002, The University of Chicago.

1 This hypothetical is based on the facts of Walker $v$ Crigler, 976 F2d 900, 901-02 (4th Cir 1992).

2 This Comment argues only that owners should not be held liable on the basis of a nondelegable duty. Because every federal court to hear the issue has considered the standard of liability to be either traditional agency principles or a nondelegable duty, the Comment will not consider the possibility that innocent owners should not be liable at all for their employees' discrimination. Moreover, although it advocates adoption of traditional agency principles, this Comment does not discuss in detail whether owners should be held liable as a matter of law on the basis of the "apparent authority" or "aided in the agency" exceptions to the scope-ofauthority rule. For an explanation of these exceptions, see notes 26-30 and accompanying text. While these concepts may become more relevant in Title VIII litigation if the approach in this Comment is adopted, see note 145, it appears that no federal court has addressed the "aided in the agency" exception in the FHA context, and very few courts have addressed "apparent authority." The courts that have addressed apparent authority have found it to be a factual, rather than legal, question. See, for example, Inland Mediation Board $v$ City of Pomona, $158 \mathrm{~F}$ Supp 2d 1120,1141 n 114 (C D Cal 2001) ("Plaintiffs have ... presented evidence from which a jury could reasonably conclude that Plaintiff Cross perceived an apparent agency relationship between the defendants.").

3 Title VIII of the Civil Rights Act of 1968, Pub L No 90-284, 82 Stat 81, codified as amended at 42 USC $\S \S 3601-31$ (1994).

4 Even though the nondelegable duty is technically a species of direct, not vicarious, liability, see Part I.B, it is discussed in the context of vicarious liability in the Restatement (Second) of Agency. See Restatement (Second) of Agency \$ 219(c) (ALI 1958). This Comment, therefore, distinguishes between an agency approach without the concept of a nondelegable duty and a system of liability based on the concept of a nondelegable duty. The Comment terms the former "traditional" principles of agency law and the latter a "nondelegable duty"

5 Courts apply traditional agency principles to determine the liability of both the owner of the property, see Cabrera v Jakabovitz, 24 F3d 372, 385-91 (2d Cir 1994) (finding that the owner of a property was vicariously liable for the damages caused by his brokers' discrimination), and
} 
for any compensatory damages ${ }^{6}$ awarded because of their employees' housing discrimination. ${ }^{7}$ Under these principles, innocent owners will be liable only if they were in an agency relationship with the employees who discriminated, and only if the discrimination occurred within the scope of the employees' authority. ${ }^{8}$ This rule affords owners the opportunity to avoid liability by instructing their employees not to discriminate and by taking steps to ensure they do not do so, because such actions will make it less likely that discrimination will be considered within the scope of authority.

Under the current law, some courts determine innocent owners' liability for compensatory damages according to an alternative theory of liability. These courts have found that the FHA also creates in own$\operatorname{ers}^{10}$ a nondelegable duty to ensure that their employees do not dis-

the owner of any brokerage firm that the owner of the property might have hired. See City of Chicago v Matchmaker Real Estate Sales Center, Inc, 982 F2d 1086, 1096-98 (7th Cir 1992) (finding the owner of a brokerage firm vicariously liable for the damages caused by his employees' discrimination). For ease of reference, this Comment will refer to both of these types of owners as "owners" or "owner."

6 Punitive damages, on the other hand, are governed by separate rules. While the current state of punitive damage law under the FHA is uncertain - see, for example, Timothy J. Moran, Punitive Damages in Fair Housing Litigation: Ending Unwise Restrictions on a Necessary Remedy, 36 Harv CR-CL L Rev 279, 317-41 (2001) (arguing that punitive damages are necessary for enforcement of the FHA)-they seem to be governed by traditional agency principles, with the exception that, "an employer [can] not be held liable [for punitive damages] for the discriminatory employment decisions of managerial [or lower-ranked] agents where these decisions are contrary to the employer's good faith efforts to comply with civil rights laws." Alexander $v$ Riga, 208 F3d 419, 433 (3d Cir 2000), quoting Kolstad v American Dental Association, 527 US 526, 545 (1999). A detailed discussion of punitive damages is outside the scope of this Comment.

7 Cabrera, $24 \mathrm{F3d}$ at 385 ("To hold [the defendant owners] vicariously liable for [the defendant brokers'] discriminatory practices, the [plaintiff] must establish that [the owners] employed [the brokers] as their agent."); Marr v Rife, 503 F2d 735, 741 (6th Cir 1974) ("The discriminatory conduct of an apartment manager or rental agent is, as a general rule, attributable to the owner and property manager of the apartment complex both under the doctrine of respondeat superior and because the duty to obey the law is non-delegable."); Matchmaker, 982 F2d at $1096 \mathrm{n} 12$ ("[ $[\mathrm{T}]$ he discriminatory acts of the four Matchmaker agents in this case were within the scope of their employment."); Northside Realty Associates, Inc v United States, 605 F2d 1348, 1354 (5th Cir 1979) ("Given [the agency] relationship, the sales agents' acts-clearly carried out within the scope of their employment and for the benefit of the [owner]-could properly be imputed to the owner.").

8 See, for example, Cabrera, 24 F3d at 388 n 16 ("Because we decide that the [owners] are liable for [their agents'] discrimination under traditional doctrines of respondeat superior, we do not need to consider whether they might also be liable because landlords may have a nondelegable duty not to discriminate."). The rules of vicarious liability are slightly more complex than this general statement. See notes 26-30 and accompanying text.

9 The rule would afford owners only the possibility, not the certainty, of avoiding liability. Restatement (Second) of Agency $\$ 230$ ("An act, although forbidden, or done in a forbidden manner, may be within the scope of employment.") (emphasis added).

10 The nondelegable duty arises against both the owner of the property-see Walker, 976 F2d at 904-05 (holding that the owner of a property has a nondelegable duty to prevent discrimination by a broker) - and the owner of any brokerage firm the owner of the property might have hired-see Holley v Crank, 258 F3d 1127, 1131 (9th Cir 2001) (holding that the owner of a brokerage firm has a nondelegable duty to prevent discrimination by a broker). There may be 
criminate against prospective tenants." This second theory of liability holds owners liable as a matter of law for any compensatory damages awarded because of their employees' discrimination. Owners face liability in every case, even if they instructed their employees not to discriminate. $^{12}$

The nondelegable-duty approach to owner liability misinterprets the FHA. First, the text does not reveal a congressional intent to impose a nondelegable duty. Second, relevant administrative regulations counsel for the application of traditional agency principles. Third, the early cases cited for the proposition that the Act creates a nondelegable duty do not, in fact, impose the duty. And fourth, the nondelegable duty does not advance the policies of the Act better than does liability based on traditional agency principles.

This Comment presents the case against a nondelegable duty on owners to prevent FHA violations. Part I discusses the difference between vicarious liability pursuant to traditional agency principles and direct liability pursuant to a nondelegable duty. Part II examines the difference between the two approaches as applied to FHA litigation. Through examination of the relevant sources, Part III argues that courts should find that the FHA does not create a nondelegable duty, and that the courts should instead determine innocent owners' liability according to traditional agency principles.

\section{VICARIOUS AND DIRECT LIABILITY}

A claim under the FHA is similar to an action in tort. ${ }^{13}$ In tort actions, agency law determines whether an employer will be liable for

reasons why these two types of owners should be considered distinct analytic categories, but this Comment does not consider them.

11 See Holley, $258 \mathrm{F3d}$ at 1132 ("[I]f [the defendant] owned [the company whose brokers discriminated] at the time of the discriminatory acts at issue, he cannot relinquish the responsibility for preventing such discrimination to another party.); Alexander, 208 F3d at 433 ("Here we adopt the general rule applied by other federal courts that the duty of a landlord under the Fair Housing Act not to discriminate in the leasing of property may not be delegated to the landlord's employee."); Walker, 976 F2d at 904 (holding that property owners have a nondelegable duty to prevent discrimination); Asbury v Brougham, 866 F2d 1276, 1280 n 4 (10th Cir 1989) ("The duty of the owner ... to obey the laws relating to racial discrimination is non-delegable."), quoting Phiffer v Proud Parrot Motor Hotel, Inc, 648 F2d 548, 552 (9th Cir 1980); Marr, 503 F2d at 741 ("The discriminatory conduct of an apartment manager or rental agent is, as a general rule, attributable to the owner and property manager of the apartment complex both under the doctrine of respondeat superior and because the duty to obey the law is non-delegable.").

12 See Walker, 976 F2d at 905 (finding the owner of a property liable for damages caused by his broker's discrimination, despite the fact that the owner instructed the broker not to discriminate).

13 See Curtis $v$ Loether, 415 US 189, 195 (1974) (holding that claims under the FHA are "analogous to a number of tort actions recognized at common law" and therefore come under the aegis of the Seventh Amendment). 
the unlawful acts of an employee. ${ }^{14}$ Agency concepts are relevant in FHA litigation when an owner does not unlawfully discriminate against a prospective tenant from a protected class, but has an employee who does discriminate without the owner's knowledge or consent. ${ }^{15}$ Under the FHA, courts will apply federal law to determine whether the innocent owner is liable for the employee's discrimination. ${ }^{16}$ This law is adapted from the Restatement (Second) of Agency."

The Restatement distinguishes between a general set of rules governing traditional agency principles of vicarious liability and a nondelegable duty leading to direct liability. In order to comprehend the doctrinal difference between these two approaches to compensatory damages under the FHA, it is necessary first to understand them as the Restatement presents them.

\section{A. Vicarious Liability Pursuant to Traditional Agency Principles}

Under the Restatement, a principal is one who employs an agent to act on his or her behalf. ${ }^{18}$ In order for an agency relationship to exist, a principal must control, or have the right to control, the conduct of the employee in the performance of the service for which the agent was employed. ${ }^{19}$ Because of this control, a principal is liable for damages caused by the acts of an agent committed within the scope of authority. ${ }^{20}$

To be within the scope of authority, an agent's conduct must be of the type that the agent was employed to perform and must be undertaken with the purpose of serving the principal. ${ }^{21}$ Even if an agent performs an intentionally tortious act that the principal has specifically

14 See generally Restatement (Second) of Agency.

is See Cabrera, 24 F3d at 385 ("To hold [the defendant owners] vicariously liable for [their brokers'] discriminatory practices, the [plaintiff] must establish that [the owners] employed [the brokers] as their agent.").

16 See id at $386 \mathrm{n} 13$ ("[W]hether an agency relationship exists for purposes of the Fair Housing Act is determined under federal law.").

17 See id at 386 (citing Restatement (Second) of Agency $\$ 1$ comment b); Matchmaker, 982 F2d at 1096 n 12 (citing \& 230); Dillon v AFBIC Development Corp, 597 F2d 556, 562 (5th Cir 1979) (citing § 219(1)).

18 See Restatement (Second) of Agency § 1(1) ("Agency is the fiduciary relation which results from the manifestation of consent by one person to another that the other shall act on his behalf and subject to his control, and consent by the other so to act.").

19 See id § 2(1) ("A master is a principal who employs an agent to perform service in his affairs and who controls or has the right to control the physical conduct of the other in the performance of the service.").

20 See id § 219 comment a ("The conception of the master's liability to third persons appears to be an outgrowth of the idea that within the time of service, the master can exercise control over the physical activities of the servant.").

21 See id $\S 228(1)$ ("Conduct of a servant is within the scope of employment if, but only if: (a) it is of the kind he is employed to perform; ... [and] (c) it is actuated, at least in part, by a purpose to serve the master."). 
forbidden, the act can still be within the scope of authority. ${ }^{2}$ A principal's admonition to an agent to avoid particular acts, however, makes it less likely that an intentional tort will be within the scope of authority. It is usually for the jury to determine whether the agent's acts are sufficiently tied to the employment for the principal to be held liable. ${ }^{24}$

If an agent acts without authority, the principal will generally not be liable for the agent's torts. ${ }^{25}$ There are, however, a number of exceptions to this general rule. First, the "apparent authority" exception occurs when the agent purports to exercise a power, which he or she does not have under the employment agreement, to commit a tort, but the plaintiff does not know that the agent lacks the authority of the principal. ${ }^{27}$ Second, the "aided in the agency" exception occurs if the agency relationship facilitates an agent in the commission of the tort. While these two exceptions to the scope-of-authority rule may prove to be important in future FHA litigation, ${ }^{29}$ very few courts have addressed them in the FHA context. ${ }^{30}$ Third, and most important for the FHA, is the nondelegable duty.

\section{B. Direct Liability Pursuant to a Nondelegable Duty}

A nondelegable duty arises when a provision of law creates an obligation so important to the community that the employer will be liable for damages even if the performance of the obligation is delegated to an agent acting without authority. ${ }^{32}$ If the duty is breached, the employer will always be liable for the resulting harms. Technically, then, the term "nondelegable duty" is misleading. The performance of

22 See id $\S 230$ ("An act, although forbidden, or done in a forbidden manner, may be within the scope of employment.").

23 See id $\S 230$ comment c ("[T]he prohibition by the employer may be a factor in determining whether or not, in an otherwise doubtful case, the act of the employee is incidental to the employment.").

24 See Cabrera, 24 F3d at 388-89 (reviewing the trial judge's instruction on scope of authority).

25 See Restatement (Second) of Agency $\$ 219$.

26 In addition to the exceptions listed in the text of this Comment, the principal will be liable where "[he or she] intended the conduct or consequences,... or [he or she] was negligent or reckless." Id \$219(2).

27 Id $\S 219$ comment e ("Clause (d) includes primarily situations in which the principal's liability is based upon conduct which is within the apparent authority of a servant, as where one purports to speak for his employer in defaming another or interfering with another's business").

28 Id ("[T]he servant may be able to cause harm because of his position as agent, as where a telegraph operator sends false messages purporting to come from third persons.").

29 See note 145.

30 See note 2 .

31 Id $\S 219(2)(c)$.

32 See William L. Prosser, Handbook of the Law of Torts $\$ 71$ at 471 (West 4th ed 1971) ("It is difficult to suggest any criterion by which the non-delegable character of such duties may be determined, other than the conclusion of the courts that the responsibility is se important to the community that the employer should not be permitted to transfer it to another."). 
the duty can be delegated; it is the liability for a breach of the duty that cannot. ${ }^{33}$

For example, under the Restatement a landowner has a nondelegable duty to ensure that work on his or her land does not cause harm to others. ${ }^{34}$ Even if a landowner exercises due care in selecting and overseeing a contractor, the landowner will be liable for any injury to a third party occasioned by the contractor's negligence. ${ }^{35}$ Because the nondelegable duty imposes an obligation on the landowner to avoid harm, the landowner will be liable even if the contractor caused harm by acting outside the scope of authority. ${ }^{36}$ Unlike traditional agency principles, the nondelegable duty does not impose a vicarious standard of care. Instead, it imposes a direct obligation to ensure that harm does not befall another. ${ }^{37}$ With a nondelegable duty, the landlord is always liable for harm that befalls another because of the acts of an agent."

\section{OWNER LIABILITY UNDER THE FHA}

Many courts apply traditional agency principles to determine liability for compensatory damages under the FHA. ${ }^{39}$ Under the traditional agency paradigm, owners are generally liable for damages caused by housing discrimination by their agents acting within the scope of authority. Some courts, however, also impose on owners a nondelegable duty to avoid discrimination. ${ }^{20}$ Under this latter interpretation of the Act, owners must compensate plaintiffs for their employees' acts of discrimination that occur in the rental or purchase of the property, irrespective of whether the agent was acting with or without authority.

33 See Fowler V. Harper, et al, The Law Of Torts $\$ 26.11$ at 83 (Little, Brown 2d ed 1986) ("Defendants who are under such a duty cannot, by employing a contractor, get rid of their own duty to other people, whatever that duty may be.") (internal quotation marks omitted).

34 See Restatement (Second) of Torts $\$ 422$ (ALI 1965) ("A possessor of land who entrusts to an independent contractor ... work on the land ... is subject to the same liability as though he had retained the work in his own hands to others on or outside of the land.").

35 See id $\S 422$ comment c, illustration 1 ("A, the owner of a department store, employs an independent contractor.... [T] he monitor [the contractor is constructing] is insecurely fastened, and falls through the skylight, injuring $B$, a customer....A is subject to liability to B.").

36 See id Ch 15 , topic 2, Introductory Note ("[A] 'non-delegable duty' requires the person upon whom it is imposed to answer for it that care is exercised by anyone, even though he be an independent contractor.").

37 See Prosser, Law of Torts $\$ 71$ at 470 (cited in note 32) ("[T] he cases of "non-delegable duty' ... hold the employer liable for the negligence of the contractor, although he has himself done everything that could reasonably be required of him.").

38 See Restatement (Second) of Torts $\$ 422$.

39 See note 7.

40 See note 11. 


\section{A. Application of Traditional Agency Principles}

The courts that evaluate owner liability for compensatory damages based on agency principles first consider whether the employee who discriminated is an agent of the owner, and if so, whether the discrimination occurred within the employee's scope of authority. ${ }^{41} \mathrm{Be}-$ cause agency and scope of authority are typically jury questions, the court's role is usually limited to examining whether the facts support the jury's findings.

In City of Chicago v Matchmaker Real Estate Sales Center, Inc, for example, one defendant was the CEO and sole proprietor of a real estate brokerage firm. ${ }^{4}$ The CEO had established several written policies requiring his brokers to comply with fair housing laws. ${ }^{45}$ Nevertheless, the firm's brokers unlawfully discriminated against prospective buyers. At the bench trial, the judge found that the CEO was vicariously liable for the compensatory and punitive damages caused by his employees' discrimination. ${ }^{47}$

In upholding the award of compensatory damages, the court in Matchmaker applied the traditional principles of agency law. ${ }^{43}$ The

41 See Cabrera, 24 F3d at 385-89 (upholding the trial court's decisions (1) to present the question of agency to the jury and (2) to refuse to instruct the jury that the owner must actually authorize the discrimination for it to be within the scope of authority).

42 See id.

43982 F2d 1086 (7th Cir 1992).

44 Id at 1093.

45 Id at 1093-94.

46 Id at 1089-93 (finding that the brokers had engaged in unlawful racial steering).

47 Id at 1094.

48 Unfortunately, the opinion in Matchmaker is not a model of clarity on the issue. There is one sentence in the opinion that says, "[a] principal cannot free itself of liability by delegating to an agent the duty not to discriminate." Id at 1096. While this sentence uses the language of nondelegability, it does not mean that the court applied the nondelegability rule. Immediately preceding the quoted language the court stated:

The doctrine of respondeat superior enables the imposition of liability on a principal for the tortious acts of his agent and, in the more common case, on the master for the wrongful acts of his servant. As a matter of well-settled agency law, a principal may be held liable for the discriminatory acts of his agent if such acts are within the scope of the agent's apparent authority, even If [sic] the principal neither authorized nor ratified the acts.

Id (internal citations omitted). Not only is this language indubitably that of a traditional agency analysis, it is what drives the opinion. The lower court found that the owner was liable for the agents' discrimination despite the fact that the owner instructed them not to discriminate, a finding that the court in Matchmaker upheld. Id. The finding that the agents' acts were within the scope of authority (and the discussion thereof) would be superfluous if the court had been applying the nondelegability rule, because an agent does not have to be acting with authority to be liable under the nondelegability regime. See Part I.B. By applying the principles of traditional agency law, the court concluded that the principal could not discharge the duty under the FHA by instructing an agent not to discriminate under agency law, because the discrimination was within the scope of authority. Matchmaker, 982 F2d at 1096 n 12 . A rehabilitative reading of Matchmaker's use of both the language of agency and nondelegability is that the court applied 
court first found that the evidence was sufficient to support a factual finding that the brokers were agents of the CEO. ${ }^{49}$ Next, the court found that the brokers' discrimination was within the scope of their authority. ${ }^{30}$ Because agency law provides that an owner is liable for the compensatory damages caused by the torts of an agent committed within the scope of authority, ${ }^{\text {s1 }}$ the court agreed with the trial judge that the owner was liable for the plaintiffs' compensatory damages.

\section{B. Imposition of a Nondelegable Duty}

Some courts find that the FHA imposes on owners a nondelegable duty to avoid discrimination. In practical application, a nondelegable duty under the FHA means that the owner is liable for compensatory damages regardless of whether the employee who discriminated was acting within the scope of authority. ${ }^{53}$ Under this theory of liability, the owner is subject to liability for the discrimination committed by employees against prospective or current tenants, even if the owner specifically instructed the agent not to discriminate. ${ }^{\text {s }}$ Courts find that the FHA creates a nondelegable duty on three grounds: the text of the FHA, precedent interpreting the Act, and the policies embodied in Title VIII.

\section{Text.}

Courts have supported their findings that the FHA imposes a nondelegable duty on owners by relying upon the text of the Act. In United States $v$ Youritan Construction Company, ${ }^{35}$ for example, the defendants owned apartment buildings that they leased through rental

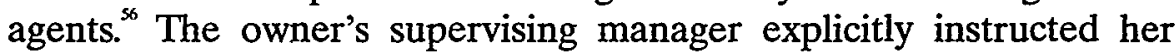
subordinates to show black applicants the most expensive apartments,

agency law, but found that, as a matter of law, discrimination is always within the scope of authority. Such an interpretation of the FHA is called into question by the Court's recent pronouncements in the Title VII context. See note 145.

49 Matchmaker, $982 \mathrm{~F} 2 \mathrm{~d}$ at 1097 (finding that the sales agents were agents of the company because of the extent of the company's training and supervision of its employees):

50 Id.

51 See Part I.A.

52 Matchmaker, 982 F2d at 1098 ("Matchmaker ... is vicariously liable for the discriminatory acts of its agents."). The court, however, disagreed with the trial judge's award of punitive damages, holding that punitive damages were inappropriate absent a finding of direct culpability. Id at 1100 .

53 See Holley, 258 F3d at 1132-33 (finding the sole officer of a brokerage firm liable without an inquiry into whether the rental agent who discriminated was acting within the scope of authority); Walker, 976 F2d at 904 ("[T] he arguable conclusion that [the manager] acted outside of the scope of her employment is irrelevant to the present case.").

54 See note 12 and accompanying text.

55370 F Supp 643 (N D Cal 1973).

56 Id at 646. 
give them incomplete tours of the complex, and misrepresent the availability of apartments to discourage them from applying for housing - all in violation of the FHA."

In finding that the owner had a nondelegable duty to prevent discrimination, the court examined the text of the FHA. In particular, the court looked at a portion of the prohibition section of the Act, which states: "It shall be unlawful to refuse to rent ... [or] otherwise make unavailable housing, or to deny housing because of race."ss The court interpreted the "otherwise make unavailable" language as making illegal "all practices which have the effect of denying dwellings on prohibited grounds." ${ }^{\text {,s9 }}$ In practical application, the court found, this language creates a two-fold prohibition: one directed at acts and the other directed at parties. ${ }^{60}$

The court found that the prohibition against discriminatory acts targeted the imposition of even minimal obstacles to the securing of housing, such as "more burdensome application procedures, [ ] delaying tactics, and [ ] various forms of discouragement." ${ }^{61}$ The court found the prohibition against parties, on the other hand, to provide for direct liability against owners who failed to ensure that their managers did not discriminate in the housing process. ${ }^{62}$ Because the language of the Act was "as broad as Congress could have made it,", the court found that Congress intended to impose on owners a nondelegable duty.

57 Id.

58 Id at 648, quoting 42 USC \& 3604(a) (1968).

59 Id.

60 Id at 649.

61 Id at 648.

62 Id ("Section 3604(a) [is also violated] by top management and owners who fail to set forth objective and reviewable procedures for apartment application and rental.").

63 Id.

64 Id at 649 ("The duty to obey the [FHA] is non-delegable."). Although the court in Youritan found that the owner has a nondelegable duty under the FHA, it interpreted the duty in such a narrow way that the owner may be able to fulfill it by implementing "objective and reviewable procedural standards." Id. In other words, the duty not to discriminate is nondelegable, unless it is, in fact, delegated. Such a finding is incompatible with the categorical nature of the nondelegability rule and appears closer to a finding according to agency principles.

The court in Youritan is not alone in this view. In Walker, $976 \mathrm{~F} 2 \mathrm{~d}$ at $905 \mathrm{n} \mathrm{10}$, although the court found the owner liable based on the rule of nondelegability, it balked in dicta at applying the rule in every situation:

We do not have occasion to address the question of whether a heightened level of supervisory activity on the part of a property owner could constitute reasonable fulfillment of his duty not to discriminate, shielding him from liability for discrimination carried out by an agent acting contrary to a specific non-discrimination program instituted by the owner. 


\section{Precedent.}

The first case to use the phrase "nondelegable duty" in FHA litigation was United States $v$ Real Estate Development." In Real Estate Development, the defendant owned a series of apartment complexes." For two years after the passage of the Act, the managers of the complexes turned away a "measurable" number of black applicants based solely on their race.

At the bench trial, the court found that the managers had violated the FHA. ${ }^{63}$ It noted that the "managers ... as agents of the defendants, are authorized to represent the defendants.... Their acts and statements, made within the scope of their agency, are attributable to the defendants, whose duty to comply with the law is non-delegable." The court, therefore, found the defendant vicariously liable on the basis of agency principles and directly liable on the basis of his breach of the FHA's nondelegable duty.

In making this pronouncement, the court did not examine the text or policy of the Act, nor did it offer any rationale for its finding that the duty created was nondelegable. Instead, the court cited only two cases in support of its ruling: Williamson $v$ Hampton Management Company ${ }^{70}$ and United States $v$ Reddoch. ${ }^{71}$ In these two cases the defendant owners, who did not themselves discriminate, were found liable for their managers' discrimination. ${ }^{2}$ The court in Real Estate Development determined that these cases stand for the proposition that the FHA imposes a nondelegable duty on owners to avoid discrimination.

3. Policy: importance of the obligation.

Courts have also justified the imposition of a nondelegable duty on the grounds that the FHA creates an obligation so important that

65347 F Supp 776 (N D Miss 1972) (holding that the housing discrimination committed by resident managers was attributable to owners).

66 Id at 779.

67 Id at 780.

68 Id at 782 ("This evidence constitutes, at least, a prima facie case of racial discrimination.").

69 Id at 785.

70339 F Supp 1146 (N D Ill 1972) (holding company liable for its management agents' discrimination in violation of the FHA).

71 No 6541-71-P slip op (S D Ala Jan 27, 1972) (holding the owners of an apartment complex liable for the FHA violations of the rental manager and her subordinates).

72 For a more detailed account of the facts of these two cases see Part III.C.2.

73347 F Supp at 785 (citing Williamson and Reddoch for the proposition that "[t]he resident manager['s] and manager['s] ... acts and statements ... are attributable to the defendants, whose duty to comply with the law is non-delegable"). 
the owner should not be able to transfer it to another. ${ }^{74}$ In Walker $v$ Crigler, ${ }^{75}$ for example, the defendants were the owner and manager of a rental property. ${ }^{76}$ The owner had instructed the manager not to discriminate unlawfully in the rental of the property. ${ }^{7}$ In contravention of the owner's demands, the manager refused to rent to the plaintiff solely because she was a woman. ${ }^{78}$ The jury found that the owner was not liable for the discrimination because it considered the discrimination to be outside the manager's scope of authority. ${ }^{79}$

The appellate court in Walker reversed, holding that the owner was liable for compensatory damages caused by a breach of the FHA's nondelegable duty. ${ }^{80}$ The court focused on the policy of the Act, ${ }^{81}$ which is "to provide, within constitutional limitations, for fair housing throughout the United States." reveals the "overriding societal priority" of the Act's prohibitions, and therefore justifies imposing a nondelegable duty.

The court found that forcing the owner to account for harm caused by an employee's discrimination best fulfills the twin aims of the Act-deterrence and compensation. Under the nondelegability regime, "the one innocent party with the power to control the acts of the agent, the owner of the property, ... must act to compensate the injured party for the harm, and to ensure that similar harm will not occur in the future."

a) Deterrence. The court implicitly found that the nondelegability regime is more effective in deterring violations of the Act than a regime based on traditional agency principles would be. ${ }^{85}$ Under a traditional agency regime, owners must only monitor their agents acting with authority to avoid liability under the FHA. ${ }^{86}$ Under a nondelega-

74 See Prosser, Law of Torts $\S 71$ at 471 (cited in note 32); Walker, 976 F2d at 904 ("In many cases, involving issues other than housing discrimination, [] a finding [that the owner did not confer on the agent the right to discriminate] would ... shield [the owner] from any liability as principal. However, [that] is irrelevant in the present case.").

75976 F2d 900 (4th Cir 1992).

76 Id at 901-02.

77 Id at 902 (finding that the owner had sent the manager a memorandum explicitly instructing her not to discriminate).

78 Id.

79 Id at 903 (noting that "[t]he jury ruled on the case against [the owner] in his favor, holding, apparently, that [the manager] was not acting in the scope of her employment when she denied [plaintiff]'s attempts to rent the ... premises because she was a woman").

80 Id at 903-04.

81 Id at 904.

8242 USC $\$ 3601$.

83 Walker, 976 F2d at 904.

84 Id at $904-05$.

85 Id at 905 ("[W] must hold [owners] to the specific mandates of anti-discrimination law if the goal of equal housing opportunity is to be reached.").

86 See Part I.A. 
bility regime, on the other hand, owners are forced to monitor their agents acting without authority to avoid FHA liability.

To the extent that the additional monitoring and the costs it imposes are less burdensome than the costs of litigation and the ensuing liability, owners, under the nondelegability rule, should choose to monitor their agents acting without authority. ${ }^{88}$ This additional monitoring should, in theory, lead to fewer infractions of the FHA than would exist under a traditional agency regime."

b) Compensation. In addition, the court in Walker implicitly found that the nondelegability rule better fulfills the compensation policy of the Act than a traditional agency analysis. ${ }^{\circ}$ Under a traditional agency regime, owners are not liable for discrimination committed by agents acting without authority. ${ }^{\text {9 }}$ In these situations, the aggrieved plaintiff would have to seek damages against the employee directly.

The nondelegability rule, unlike the traditional agency analysis, does not examine whether the discriminatory actions were undertaken with authority. Instead, the owner must always compensate the plaintiff for the employee's discriminatory acts. ${ }^{93}$ Assuming that employees will, more often than owners, be unable to satisfy judgments against them, ${ }^{\text {gt }}$ the nondelegability regime should lead to more plaintiff compensation than under a traditional agency analysis.

\section{THE NONDELEGABILITY RULE SHOULD BE ABANDONED}

The finding that owners have a nondelegable duty to avoid discrimination is an incorrect interpretation of the Act's standard of liability. In determining the standard of liability under an antidiscrimination statute, federal courts must look at the text of the act," the act's administrative regulations, ${ }^{96}$ precedent, ${ }^{97}$ and the policy be-

87 See Part I.B.

88 See Corina R. Caplan, Note, The Decline and Recent Revival of Absolute Vicarious Liability Under the Fair Housing Act, 48 Rutgers L Rev 581, 608 (1996) ("[S]uppliers will invest more heavily in prevention under non-delegability, and less discrimination will occur than under the agency rule.").

89 See id.

90 See Walker, $976 \mathrm{~F} 2 \mathrm{~d}$ at 904-05 (finding that, as between the innocent owner and the innocent potential renter, the owner must "bear the burden of the harm caused").

91 See Part I.A.

92 See Walker, 976 F2d at 904 ("[T]he arguable conclusion that [the manager] acted outside the scope of her employment is irrelevant in the present case.").

93 See Part I.B.

94 See Alan O. Sykes, The Economics of Vicarious Liability, 93 Yale L J 1231, 1235 (1984) (noting that agents are "often individuals of limited means").

95 See Burlington Industries, Inc v Ellerth, 524 US 742, 754 (1997) (examining the text of Title VII in determining its standard of vicarious liability for sexual harassment).

96 See id at 755 (noting that "the EEOC has issued Guidelines governing sexual harass- 
hind the act. ${ }^{93}$ None of these sources supports the holding that the FHA creates a nondelegable duty.

Section A of this Part will show that the text of the Act falls short of pointing to a congressional intent to impose a nondelegable duty. Section B will demonstrate that the administrative agency charged with enforcing the Act has promulgated regulations that rely on traditional concepts of agency liability. Section $C$ will argue that the early cases do not establish that the FHA creates a nondelegable duty. Section $\mathrm{D}$ will conclude that the imposition of a nondelegable duty contradicts prior interpretations of other civil rights statutes and, in actual application, does not fulfill the policies of the Act.

\section{A. The Text of the Act Does Not Reveal a Congressional Intent to Impose a Nondelegable Duty}

The text of the FHA does not support imposition of a nondelegable duty. Although there are no firmly established textual criteria for determining whether a statute imposes such a duty, the Restatement delineates the conditions under which a statute will be read to do so:

One who by statute or administrative regulation is under a duty to provide specified safeguards or precautions for the safety of others is subject to liability to the others for whose protection the duty is imposed for harm caused by the failure of a contractor employed by him to provide such safeguards or precautions. ${ }^{100}$

Courts have followed two general textual principles in determining whether a statute meets these conditions. If the statute identifies the party on whom an obligation rests and specifically states the precautions the party must take to fulfill the obligation, courts will find a nondelegable duty. ${ }^{101}$ The FHA satisfies neither of these conditions. It provides:

ment claims under Title VII, but they provide little guidance").

97 See id ("[F]ederal courts have explored agency principles, and we find instruction in their decisions.").

98 See Faragher $v$ City of Boca Raton, 524 US 775, 797-808 (1998) (examining the policies of Title VII in applying a standard of liability for sexual harassment). It is commonplace for courts also to examine the legislative history of the FHA, which provides no evidence regarding Congress's intended standard of liability. See Kaplan, 48 Rutgers L Rev at 600 (cited in note 88) ("The legislative history of the FHA offers little revelation of Congress's intent.").

99 This Part does not argue that the language of the FHA affirmatively reveals a congressional intent to apply agency principles. Instead; it only shows that the nondelegability reading is incorrect, and that the text is unclear. For a discussion of the implications of this lack of clarity, see note 148.

100 Restatement (Second) of Torts $\$ 424$.

101 See 41 Am Jur 2d Ind Con $\$ 48$ (1995) ("Generally, if a statute or municipal ordinance requires one to do a certain thing or to take certain precautions for the protection of persons on 
[I]t shall be unlawful ... [t]o refuse to sell or rent after the making of a bona fide offer, or to refuse to negotiate for the sale or rental of, or otherwise make unavailable or deny, a dwelling to any person because of race, color, religion, sex, familial status, or national origin. ${ }^{102}$

The language does not mention the word "owner" at all. Instead, the focus of the Act is on prohibitions, not parties. Moreover, it does not contain the word "duty,"103 nor on its face does it state or imply that the owner has a special obligation to ensure nondiscrimination in the sale or rental of the property. In fact, the Act states no particular affirmative obligations at all-it only prohibits particular acts. The FHA thus fails both criteria of interpretation typically applied to determine whether a statute creates a nondelegable duty.

Despite this failure, the court in Youritan found that the language of the FHA evinced a congressional intent to impose a nondelegable duty. The court interpreted the "otherwise make unavailable" language as imposing on owners a nondelegable duty not to discriminate.

This interpretation is incorrect. The word "otherwise" must have a referent; there must be something the word refers to in order for there to be an "other." In the quoted sentence, the phrase "otherwise make unavailable" refers to the unlawful acts, namely, "to refuse to sell or rent ... or to refuse to negotiate." These prohibitions are each against actions-to refuse to rent; to refuse to negotiate-not against status as an owner. Based on the maxim of statutory interpretation ejusdem generis, ${ }^{105}$ because the referent is an active verb, the "otherwise" should also be interpreted to prohibit only other actions, not to impose liability on other parties who have not discriminated in violation of the Act. ${ }^{105}$

Moreover, even assuming that the court's reading is correct, it should be rejected because it leads to an absurd result. The word "oth-

\footnotetext{
or near his or her property, such person cannot delegate that duty to an independent contractor and be released from liability in case the contractor fails to perform it."); Christopher P. Bennett, Note, The Buck Stops Here: Peaceable Repossession Is a Nondelegable Duty, 63 Mo L Rev 785, 788 (1998) ("Ordinarily, the language of the statute or ordinance must subject the employer to a definite obligation.").

10242 USC $\$ 3604$ (a).

103 See General Building Contractors Association v Pennsylvania, 458 US 375, 396 (1982) (interpreting 42 USC $\$ 1981$ not to impose a nondelegable duty and finding it instructive that "[t]he language of the statute does not speak in terms of duties").

104370 F Supp at 648. See also Part II.B.1.

105 "Of the same kind, class, or nature."

106 Compare Circuit City Stores, Inc v Adams, 532 US 105, 115 (2001) ("Under this rule of construction the residual clause should . . . be controlled and defined by reference to the enumerated categories ... which are recited just before it.").
} 
erwise" is in only two of the six sections containing prohibitions in the FHA. ${ }^{107}$ The court's reading would therefore impose a nondelegable duty on the owner for "refus[ing] to sell or rent" on the basis of membership in a protected class, but not for "represent[ing] to [a member of a protected class] that any dwelling is not available for inspection, sale, or rental., ${ }^{, 103}$ This result is absurd-both prohibitions target very similar acts of discrimination-and it seems likely to have been unintended by Congress; there is no reason why these two provisions should establish different standards of liability. ${ }^{109}$ Because courts should not ascribe to Congress an intent to create unreasonable provisions of law absent a clear indication, ${ }^{110}$ the Youritan reading should not be accepted.

\section{B. HUD Regulations Favor the Application of Agency Principles}

Like the text of the Act, the administrative regulations implementing the FHA do not counsel for the imposition of a nondelegable duty. Instead, HUD's regulations indicate that the courts should apply traditional agency principles.

The FHA explicitly gives the Secretary of HUD the power to administer the Act. ${ }^{11}$ Pursuant to this delegation, the Secretary has promulgated regulations interpreting the provisions of the Act and providing for enforcement procedures ${ }^{112}$-regulations that are entitled to "considerable deference."113 While HUD's regulations do not specifically interpret the Act's civil remedy to provide for traditional agency principles, the regulations do provide for the application of traditional agency principles in the administrative proceedings. The fact that liability in the administrative proceedings is determined according to traditional agency principles provides strong evidence that the standard of liability under the civil side of the Act should also come from the traditional agency regime.

107 See 42 USC $\S 3604$ (a), (f)(1). Section 3604(f)(1) states that it shall be unlawful to "discriminate in the sale or rental, or to otherwise make unavailable or deny, a dwelling to any buyer or renter because of a handicap."

103 Compare 42 USC \$ 3604(a) with 42 USC \$ 3604(d).

109 Compare Green v Bock Laundry Machine Co, 490 US 504, 528-30 (1989) (Scalia concurring) (interpreting Federal Rule of Evidence $609(\mathrm{a})(1)$ against the plain meaning of the text of the rule, where the absurd result was likely unintended).

110 See Cass County v Leech Lake Band of Chippewa Indians, 524 US 103, 112 (1998) ("Indeed, because such congressional purpose would be unreasonable, Congress would have to clearly manifest such a contrary purpose.") (internal quotation marks omitted).

11142 USC $\$ 3608$.

112 See 24 CFR $\$ \$ 1.1$ et seq (2000).

113 Harris v Itzhaki, 183 F3d 1043, 1052 (9th Cir 1999). See also Chevron USA, Inc v Natural Resources Defense Council, 467 US 837, 843 (1984) (finding that if "Congress has not directly addressed the precise question at issue ... [t] $]$ he question for the court is whether the agency's answer is based on a permissible construction of the statute"). 
The FHA provides that claimants may bring either a civil action or an administrative claim. ${ }^{14}$ HUD's regulations regarding who may be sued in an administrative FHA claim have historically provided that "[a] complaint may [ ] be filed against any person who directs or controls, or has the right to direct or control, the conduct of another person ... if that other person [is] acting within the scope of his or her authority as [an] employee or agent." 11

The regulation clearly limits the conditions under which an innocent owner may be subject to liability for the acts of an employeethe owner must either direct or control, or have the right to direct or control, the conduct of the employee, and the employee must be acting within the scope of authority. These two requirements map those of an agency analysis. ${ }^{116}$

114 See 42 USC $\S 3610$ (administrative actions); $\$ 3613$ (civil actions).

11524 CFR \& 103.20 (1999) (repealed). The new language provides that "the Assistant Secretary will serve notice on any person who directs and controls, or has the right to direct or control, the conduct of another who is involved in a fair housing complaint." 24 CFR $\S 103.202$ (b) (2000). In Holley, $258 \mathrm{~F} 3 \mathrm{~d}$ at $1131 \mathrm{n} \mathrm{1,} \mathrm{the} \mathrm{Court} \mathrm{interpreted} \mathrm{the} \mathrm{amendment} \mathrm{as} \mathrm{making} \mathrm{no} \mathrm{sub-}$ stantive change to the old language. ("Absent any indication that HUD intended to narrow liability under the new regulations, we find the previous language instructive regarding the potential scope of liability."). Indeed, the amendment was promulgated pursuant to former President Bill Clinton's directive to administrative agencies to use plain language in their regulations. Plain Language in Government Writing: Memorandum for the Heads of Executive Departments and Agencies, 63 Fed Reg 31885 (1998). HUD noted specifically that pursuant to this directive, it would "[a]void surplus words and technical legal jargon." Department of Housing and Urban Development, Fair Housing Complaint Processing: Plain Language Revision and Reorganization, 64 Fed Reg 18538 (1999). In addition, it stated that the amendment "[d]oes not change the substance of the existing ... regulations." Id at 18539.

116 In addition, HUD's comments on the regulation indicate that liability should be determined by traditional agency principles. In fact, the nondelegability approach was considered but rejected in promulgating $\$ 103.20$. HUD's proposed rule on the standard of liability under the Act initially omitted the reference to "scope of authority," Department of Housing and Urban Development, Proposed Rule, 49 Fed Reg 40533 (1984), and the commentary suggests that HUD intended to impose a "nondelegable" duty on owners. See id at 40528-29. In response to strong objections over the nondelegability interpretation, HUD added the "scope of authority" language. The comments to the final rule show that HUD clearly rejected the nondelegable duty:

[I]t is not HUD's intent to impose absolute liability on any principal; the intent, in proposing [ $\$ 103.20]$, was to follow the law enunciated by the courts in recent Fair Housing Act cases with respect to the liability of a principal for acts of an agent.... HUD has revised the language of [\$103.20] to provide that a complaint may be filed against a directing or controlling person with respect to the discriminatory acts of another only if the other person was acting within the scope of his or her authority as employee or agent of the directing or controlling person.

Department of Housing and Urban Development, Final Rule, 53 Fed Reg 24185 (1998) (emphasis added). HUD affirmed its commitment to agency principles in restructuring its complaint procedures in 1989, see Department of Housing and Urban Development, Implementation of the Fair Housing Act Amendments of 1988, 54 Fed Reg 3232, 3261 (1989), and also in 1999. See note 115.

Despite the clear text and comments on section 103.20, there have been several HUD adjudications in which the administrative law judge has found that the FHA creates a nondelegable duty in owners. See, for example, HUD v Schmid, 1999 WL 521524 at *5 (HUD ALJ July 15, 
This provision, however, governs only those claims filed with the Secretary of HUD; the regulations make no mention of who may or may not file a civil claim in district court. Nevertheless, courts have found that the administrative and civil remedies should be interpreted as "alternate analogous remedies." In Marr $v$ Rife, ${ }^{118}$ for example, one issue before the court was the burden of proof in civil FHA claims." While the Act itself does not state which party has the burden in civil claims, in administrative claims the complainant carries the burden. In response to the plaintiff's argument that the burden of proof should shift to the defendants once a prima facie case was made, the court stated:

1999) ("The duty of property owners not to discriminate is non-delegable."), citing US $v$ Gorman Towers Apartment, 2 Fair Housing-Fair Lending (P-H) II 15942 at 15942.4 (1994). These cases clearly contradict HUD's own binding regulations and should be rejected outright. See St Luke's Methodist Hospital $v$ Thompson, 182 F Supp 2d 765, 775 (N D Iowa 2001) ("When ... the issue is whether the agency has erred in interpreting its own regulations, the plain meaning of a statute or regulation controls, if there is one, regardless of an agency's interpretation.").

Moreover, even if the regulation commanding the application of agency principles were ambiguous, the adjudicatory orders purporting to establish that the FHA imposes a nondelegable duty are a circumvention of the rulemaking process. While administrative agencies have wide discretion to decide whether to proceed by rulemaking or adjudication, "there may be situations where the reliance on adjudication would amount to an abuse of discretion." See NLRB v Bell Aerospace Co, 416 US 267, 294 (1974). One example of an abuse of discretion is when the adjudicatory order attempts to resurrect a requirement that was previously rejected by a notice-andcomment rulemaking. See Patel v INS, 638 F2d 1199 (9th Cir 1980) (striking down the INS's adjudicatory imposition of a visa requirement that had been considered and rejected from a previous rulemaking); William D. Araiza, Agency Adjudication, the Importance of Facts, and the Limitations of Labels, 57 Wash \& Lee L Rev 351 (2000) (validating the Patel approach). See also National Family Planning \& Reproductive Health Association v Sullivan, 979 F2d 227, 240 (DC Cir 1992) (striking down the HHS's adjudicatory lifting of a referral ban when the previous rule disallowing the referrals had been promulgated in rulemaking); Michael Asimow, Nonlegislative Rulemaking and Regulatory Reform, 1985 Duke L J 381, 396 ("If a second rule repudiates or is irreconcilable with a prior legislative rule, the second rule must be an amendment of the first; and, of course, an amendment to a legislative rule must itself be legislative.").

As in Patel, the HUD adjudicatory orders finding that the FHA creates a nondelegable duty contradict the rejected proposal in promulgating $\S 103.20$. The orders, therefore, represent a circumvention of the rulemaking process, and should be struck down. Indeed, "[t]o sanction any other course would render the requirements of [the Administrative Procedure Act] basically superfluous in legislative rulemaking by permitting agencies to alter their requirements for affected public members at will through the ingenious device of 'reinterpreting' their own rule." Sullivan, 979 F2d at 231-32.

117 Holley, 258 F3d at 1131. See also Gladstone Realtors $v$ Village of Bellwood, 441 US 91, 104 (1979) (finding that "Congress intended to provide all victims of Title VIII violations two alternate mechanisms by which to seek redress"); Marr, 503 F2d at 739 (analogizing the civil remedy under the Act to the administrative remedy). But see Walker, 976 F2d at 904 (concluding that because the regulation only purports to govern administrative claims, by its own terms it does not apply to civil claims).

118503 F2d 735 (6th Cir 1974).

119 Id at 738 (concluding that it was necessary to rule on whether "the District Judge erred in holding that plaintiffs had the burden of proving their case by a preponderance of the evidence").

120 See id at 739. 
Although [the Act's provision of a civil remedy] fails to indicate the burden of proof to be applied, it would be anomalous for a different burden of proof to apply [in the civil remedy] than is applied [in the administrative remedy]. By adopting [the] suggested burden of proof, we would virtually eliminate any reason for seeking voluntary enforcement [by the Secretary of HUD] under [the administrative procedures]. ${ }^{121}$

Likewise, it would be anomalous to read the standard of liability in civil FHA claims to be a nondelegable duty while reading the standard in administrative claims to be agency principles. In addition, if the standard of liability for civil claims is more favorable to plaintiffs than the standard in the administrative remedy, then, as with the burden of proof at issue in Marr, the Secretary of HUD would be discouraged from initiating administrative claims. Therefore, HUD's regulations counsel courts to import traditional agency principles into their interpretation of the standard of liability under the Act.

\section{The Interpretive History of the Act Does Not Favor Imposition of a Nondelegable Duty}

An examination of the cases supporting imposition of a nondelegable duty under the FHA reveals that the rule's pedigree is not as strong as it may initially appear. First, because the rule is an alternative holding to a traditional agency analysis, and because juries have typically found owners to be liable on the basis of traditional agency principles, the courts rarely have had occasion to apply a nondelegable duty. Second, the cases that Real Estate Development cited in support of the nondelegable duty do not stand for that rule. Instead, they clearly applied traditional agency principles. Because every subsequent application of the nondelegable duty can ultimately be traced to Real Estate Development, this fact impugns the entire line of cases.

\section{The problem of alternative holdings.}

Examining the history of the nondelegability rule in FHA litigation, Judge Widener of the Fourth Circuit argued in dissent in Walker that the cases cited by the majority finding that the FHA creates a nondelegable duty did not, in fact, have occasion to apply the rule. ${ }^{\text {in }}$ Instead, he argued that the courts decided each of these cases by the application of traditional agency principles. ${ }^{123}$ Once the owner was held

121 Id.

122 Walker, 976 F2d at 907-08 (Widener dissenting) (dissenting on the grounds that the Fair Housing Act did not create a nondelegable duty on the owner).

123 Id. Judge Widener examined, among others, Real Estate Development, 347 F Supp 776, Marr, 503 F2d 735, and Youritan, 370 F Supp 643, concluding that he was "aware of no case 
liable on the basis of agency principles, the court's determination that he or she had a nondelegable duty was extraneous to the holding. Widener argued that the "rule," therefore, was nothing but dicta. ${ }^{125}$

Real Estate Development provides an excellent example of Judge Widener's argument. In that case, the court noted that the managers' "acts and statements, made within the scope of their agency, are attributable to the defendants, whose duty to comply with the law is non-delegable." ${ }^{126}$ The court, therefore, first found that the managers were agents of the owners, and that their acts were within the scope of authority. It could have ended its inquiry there; the owners were liable based on an application of the traditional principles of agency law. Instead it continued, finding that the owners had a nondelegable duty to avoid discrimination. This finding was unnecessary to the outcome of the case.

The court's approach in Real Estate Development is typical of the approach used by most subsequent courts that have found that the FHA creates a nondelegable duty. ${ }^{127}$ Therefore, while Walker itself necessarily held that the FHA creates a nondelegable duty, very few other cases have..$^{123}$ As Judge Widener observed, the case law falls "far short ... of establishing a general rule" that the FHA imposes a nondelegable duty on owners.

2. The early cases applied agency principles.

Moreover, in Real Estate Development, the first case to read the FHA to create a nondelegable duty, the cases that the court cited for that proposition do not, in fact, stand for it. In Williamson, the defendants owned and operated an apartment complex. ${ }^{130}$ In leasing the apartments, a desk clerk and assistant manager unlawfully discriminated against two black women. ${ }^{131}$

In finding the owner liable, the court undertook a traditional agency analysis:

squarely adopting [the non-delegability rule]."

124 Walker, 976 F2d at 907-08.

125 Id at 907 ("The cases fall far short, however, of establishing a general rule that traditional principles of agency law have no application [under the FHA].").

126347 F Supp at 785.

127 See note 123.

128 See, for example, Walker, 976 F2d at 904 ("Here we adopt the general rule applied by other federal courts that the duty of a property owner not to discriminate in the leasing or sale of that property is non-delegable."); Holley, 258 F3d at 1131 ("[O]ur Court has recognized that the duty to obey the laws relating to racial discrimination under the FHA is non-delegable.").

129 Walker, 976 F2d at 907 (Widener dissenting).

130339 F Supp 1146, 1149 (N D Ill 1972).

131 Id. 
[The clerk] was admittedly an agent of [the management company] .... What she said and did was with full knowledge ... of [the manager], who had the authority to approve or disapprove leases. The other defendants are chargeable with her acts and she participated in the violations found to have occurred. ${ }^{132}$

The application of traditional agency principles could not be clearer. First, the court found that the manager was an agent of the owners, and that her actions were within her authority. Second, the court made no mention of a nondelegable duty imposed by the FHA.

Likewise, in Reddoch, the court also applied traditional agency principles. The defendants were the owners and the manager of an apartment complex. ${ }^{133}$ The manager followed an explicit policy of racial discrimination and instructed her subordinates to do the same. ${ }^{13}$ At the bench trial, the court held all of the defendants liable, finding:

[The manager], as an agent of the defendants, is authorized to represent [the owners].... Her acts and statements, made within the scope of her agency, and made with the acquiescence of the owners, are attributable to the [owners], who, at least, failed to take adequate steps to assure that she would comply with the law. ${ }^{135}$

Although the court's language is somewhat ambiguous, several factors indicate that the court did not apply a nondelegable duty. First, unlike the situation in Real Estate Development, the owners in Reddoch knew about and brooked their agent's discrimination. It is clear that the owners likely would have been directly liable for the discrimination on a negligence theory, ${ }^{136}$ thus avoiding the agency/nondelegable duty debate entirely. Second, the agency relationship is expressly discussed, with the court finding that the manager's discrimination was within her scope of authority, a finding that was unnecessary if her liability was determined according to a nondelegable duty. Third, the language indicates that the owners might have delegated their duty under the FHA. The phrase "at least" in the sentence indicates that the owners could have instructed the manager not to discriminate, or taken other steps adequate to make her discrimination an act without authority. At most they could have assured her compliance with the law; at least they could have taken preventive measures adequate to shield them from liability. And fourth, the court did not undertake an examination of the Act, nor did it make a single policy argument

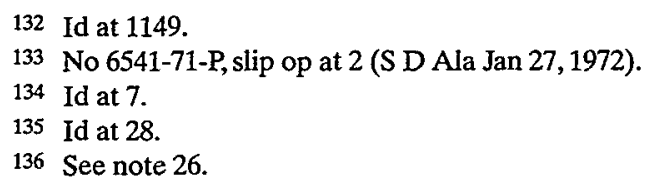


for the imposition of what would have been, at the time, an unprecedented rule in civil rights law.

\section{The Policy of the Act Does Not Support Application of a Nondelegable Duty}

Finally, courts also examine the legislation's policy to determine whether it supports the imposition of a nondelegable duty. If the statute imposes an obligation that is so important to the community that the owner should not be permitted to transfer it to another, courts will find that the duty is nondelegable. ${ }^{137}$

The FHA contains a nebulous sentence describing the importance of ending housing discrimination: "It is the policy of the United States to provide, within constitutional limitations, for fair housing throughout the United States."138 Despite the imprecision of this statement and its facial inapplicability to the standard of liability, ${ }^{139}$ it is unquestionable that the goal of ending housing discrimination is an important one. Nevertheless, precedent indicates that the obligation created under the Act should not be read to be nondelegable. This precedent comes from the Court's interpretations of two other civil rights statutes: 42 USC $\$ 1981$, enforcing the Fourteenth Amendment right of equal protection, and Title VII of the Civil Rights Act of 1964 , prohibiting discrimination in employment."

Like the FHA, each of these statutes embodies the congressional policy to deter and compensate for civil rights violations. ${ }^{1.2}$ Also like the FHA, each of these statutes has been interpreted broadly. ${ }^{143}$ But neither of these statutes imposes a nondelegable duty. Instead, $\S 1981$

137 See note 32 and accompanying text. See also Chapman v Mutual Service Casualty Insurance Co, 35 F Supp 2d 699, 706-07 (E D Wis 1999) ("Essentially, the non-delegable duty exception is based on the theory that certain responsibilities are so important that an employer or principal should not be permitted to bargain away the risks involved in performance.").

13842 USC $\$ 3601$.

139 One court has interpreted the FHA's statement of policy as indicating merely that the Act was not limited in regional scope. See Groome Resources Ltd, LLC v Parish of Jefferson, 234 F3d 192, 210 (5th Cir 2000) ("Congress acted in response to the recognition that ... there is a national effect on housing materials, economic development, and growth of certain restricted areas.").

14042 USC \& 1981 (1994).

141 Title VII of the Civil Rights Act of 1964, Pub L No 88-532 § 701, 78 Stat 253 (1964), codified as amended at 42 USC $\$ 2000 \mathrm{e}$ (1994).

142 See Catherine Fisk and Erwin Chemerinsky, Civil Rights Without Remedies: Vicarious Liability Under Title VII, Section 1983, and Title IX, 7 Wm \& Mary Bill of Rts J 755, 756 (1999) (observing that the civil rights laws "impose[] civil liability so as to deter wrongs and compensate injured individuals").

143 General Building, 458 US at 408 ("[O]ur prior decisions . . . have consistently given $\S 1981$ as broad an interpretation as its language permits.") (Marshall dissenting) (citing cases); Griggs v Duke Power Co, 401 US 424, 429-36 (1971) (finding that Title VII should be interpreted broadly to achieve equal employment opportunity). 
has been interpreted to provide for vicarious liability pursuant to traditional agency principles, ${ }^{1,4}$ and Title VII has been interpreted according to a variation of traditional agency principles, without reference to a nondelegable duty. ${ }^{145}$ Considering the similarities among $\S 1981,{ }^{146} \mathrm{Ti}-$ tle VII, ${ }^{147}$ and Title VIII, each statute should be interpreted to provide for a similar standard of liability.

144 General Building, 458 US at 396 (finding that in enacting 42 USC $\$ 1981$ Congress "did not intend to make [employers] the guarantors of the workers' rights as against third parties who would infringe them").

145 Burlington Industries, 524 US at 754-65 (although noting that the issue of nondelegability was not before it, applying agency principles to determine whether a supervisor was liable for the sexual harassment of a subordinate, and finding that, in certain cases, the employer has an affirmative defense to the supervisor's harassment, a finding inconsistent with a nondelegable duty). See also Rebecca Hanner White, Vicarious and Personal Liability for Employment Discrimination, $30 \mathrm{Ga} \mathrm{L}$ Rev 509, 562 n 125 (1996) (noting that a nondelegability approach to Title VII is inconsistent with its text and legislative history).

The analogy of Title VII to Title VIII is a particularly interesting one. In Faragher and Burlington Industries, the Court found that the issue of whether a supervisor's sexual harassment of a subordinate is within the scope of the supervisor's authority is typically a question of fact. Faragher, 524 US at 757; Burlington Industries, 524 US at 798. In each case, the Court then turned to the "aided in the agency" exception to the scope-of-authority rule. Faragher, 524 US at 802-10; Burlington Industries, 524 US at 760-65. In Faragher, 524 US at 802-03, the Court found that in some regard, a supervisor is always aided in the agency when he or she discriminates against a subordinate by virtue of the fact that the job allows the supervisor to come into contact with the subordinate. Moreover, the supervisor has some power over subordinates insofar as the employees under him or her "may well be reluctant to accept the risks of blowing the whistle." Id at 803.

Yet the Court also found that the text of Title VII and precedent interpreting it precluded a finding of absolute employer liability for the harassment committed by its supervisors. Id at 804 . In addition, the Court also found that Title VII's policy of deterrence outweighed the policy of compensation. Id at 805 . These considerations led to a distinction in the legal standard to be applied based on whether the employee suffered a "tangible employment action." Id at 807. A tangible employment action is one that "constitutes a significant change in employment status, such as hiring, fring, failing to promote, reassignment with significantly different responsibilities, or a decision causing a significant change in benefits." Burlington Industries, 524 US at 761 . When a harassing supervisor undertakes discrimination without a tangible employment action, the employer may raise an affirmative defense by showing that it had a sexual harassment policy and the plaintiff failed to take advantage of it. Id at 807 . In the case where an employee suffers a tangible employment action at the hands of a supervisor, the employer is always vicariously liable for the supervisor's discrimination according to the "aided in the agency" standard. Faragher, 524 US at 807; Burlington Industries, 524 US at 762-65.

While neither Faragher nor Burlington Industries applies directly to Title VIII, the cases raise interesting questions for the FHA: Is a supervisor in the employment context analogous to an owner in the housing context? Is a tangible employment action analogous to a denial of housing? Can violations of Title VIII be effectively deterred by nondiscrimination policies? No federal court has considered these and related questions, perhaps because the question of whether to apply agency principles or a nondelegable duty under the Act is logically antecedent to their resolution.

146 Sections 1981 and 1982 have very similar legislative histories, as both are derived from $\S 1$ of the Civil Rights Act of 1866. See General Building, 458 US at 384 . Section 1982 is often treated as the more general statutory precursor to the FHA. See Caplan, Comment, 48 Rutgers $\mathrm{L}$ Rev at 596 (cited in note 88). Therefore, just as $\S 1981$ was interpreted not to impose a nondelegable duty, the FHA should not either. Id at 594-97.

147 See, for example, Metropolitan Housing Development Corp v Village of Arlington Heights, $558 \mathrm{~F} 2 \mathrm{~d} 1283$, 1289-90 (7th Cir 1977) (reasoning that because the antidiscrimination ob- 
To be sure, the Court's interpretations of the standard of vicarious liability under these statutes have depended on the particular text and policies of each act. ${ }^{\text {ts }}$ Nevertheless, the text and policies of these statutes do not reveal that their prohibitions are somehow less important than the prohibition against discrimination in housing. It is difficult to draw the conclusion that the typical housing discrimination claim is so important that the owner should have a nondelegable duty, but, for example, plaintiffs' claims that they were prohibited from making a contract because of unlawful discrimination ${ }^{\text {is }}$ are not important enough to merit the same treatment.

Even if the policies of the Act are somehow more important than other civil rights statutes, there are reasons to think that the imposition of a nondelegable duty on owners does not significantly advance the Act's policies. Courts should consider the particularities of FHA claims in their assessment of the deterrent and compensatory effects of the nondelegability rule. First, because compensatory damage awards under the FHA are typically small, owners have little incentive to monitor their agents acting without authority. Second, because of the small damage awards, it is less likely that an employee who discriminates will be judgment proof.

1. The nondelegability rule does not serve the policy of deterrence.

The first policy justification of the nondelegability rule typically offered is that it leads to more deterrence than does the agency regime. ${ }^{1.0}$ Under the nondelegability rule, owners will be encouraged to

jectives of Title VII are parallel to the goals of Title VIII, proof of discriminatory effect will suffice to show a violation of Title VIII, just as it is sufficient under Title VII).

148 Title VII states in pertinent part that "[ $t$ ] $]$ he term 'employer' means a person engaged in an industry affecting commerce ... and any agent of such a person." 42 USC $\$ 2000$ e. In Meritor Savings Bank, FSB $v$ Vinson, 477 US 57 (1986), the Court relied on the Title VII definition in its conclusion that traditional agency principles applied to that statute. Id at 72. Although Title VIII itself does not have this exact language, HUD's regulations provide a strong analogy to Title VII. Like the statutory language of Title VII, the language of HUD's regulations counsel for the application of agency principles to Title VIII. See Part III.B.

The absence of the "agency" language in the text of the FHA itself does not provide evidence that Congress intended to impose a nondelegable duty on owners. Instead, it tends to show that Congress intended not to expose innocent owners to liability for their employees' discrimination at all. See Gebser v Lago Vista Independent School District, 524 US 274, 283 (1998) (basing its holding that Title IX does not impose liability on school districts for actions of a nonsupervisory teacher in part on the fact that Title IX lacks any reference to agency principles). Because of precedent, HUD regulations, and policy considerations, this Comment does not argue that Title VIII should be so interpreted.

14942 USC § 1981 provides that, among other civil rights, "[a]11 persons within the jurisdiction of the United States shall have the same right in every State and Territory to make and enforce contracts."

150 See Part II.B.3.a. 
monitor each of their employees, even agents acting without authority, thereby affording the employees fewer opportunities to violate the FHA."

But the theoretical deterrent value of the nondelegability rule is overstated because a breach of the nondelegable duty provides only compensatory damages under the FHA. ${ }^{152}$ Compensatory damages are generally much smaller than punitive damages under the FHA. ${ }^{1.5}$ While compensatory damages undoubtedly serve some deterrent function, their primary focus is on plaintiff compensation. ${ }^{1.4}$ Punitive damages, on the other hand, are designed to punish those who violate the Act and to deter future violations. ${ }^{155}$ Owners' liability for punitive damages under the FHA is determined according to a variation of traditional agency principles. ${ }^{1.5}$ Because of the large amount of these punitive awards, owners are already encouraged to take affirmative steps, such as issuing instructions, policies, and manuals, to ensure that their agents comply with the FHA. The relatively small compensatory damage awards, when compared to the high costs of monitoring agents acting without authority, ${ }^{157}$ likely do not provide owners with sufficient incentives to monitor their employees above what the traditional agency regime for punitive damages already requires.

In fact, the nondelegability regime might create less deterrence than a traditional agency analysis. This possibility exists because agents acting without authority have greater incentive to avoid violations of the Act under a traditional agency analysis than under the nondelegability regime.

As established, under an agency regime owners have an incentive to monitor their agents acting with authority because they will be liable if they do not. Presuming the costs of liability outweigh the costs of monitoring agents acting with authority, owners will, therefore, avoid liability by monitoring their agents acting with authority. Agents acting without authority will then themselves be deterred from violating the FHA because they alone will be liable for their discrimination.

151 Id.

152 See note 6.

153 See Moran, 36 Harv CR-CL L Rev at 344 n 55 (cited in note 6) (noting that compensatory damages "rarely exceed a few thousand dollars and often are considerably less").

154 See id at 285 (noting that compensatory damages only partially serve the policy of deterrence and are insufficient to deter FHA violations).

155 Id at 284 ("The purpose of punitive damages are [sic] to punish the wrongdoer and to deter future conduct by the tortfeasor and others.").

156 See note 6.

157 These costs are likely to be high because, by definition, the agent acting without authority is acting beyond the control of the principal. See Restatement (Second) of Agency $\$ 228(2)$ ("Conduct of a servant is not within the scope of employment if it is different in kind from that authorized."). 
Under either regime owners will have little incentive to monitor their agents acting without authority because of the high costs of monitoring and small size of the award. With a nondelegability regime, then, agents acting without authority will be deterred less than they would under an agency regime, because owners will be liable for the agents' discrimination. ${ }^{\text {iss }}$ While owners may seek contribution from the agents acting without authority, ${ }^{159}$ they will do so only if the compensatory damages are larger than the costs of the contribution action. The situation where the damages are larger than the costs of the contribution action seems unlikely given that compensatory damages under the FHA will be relatively low. Therefore, it is possible that more discrimination could occur under the nondelegability rule than under a traditional agency analysis. ${ }^{160}$

2. The nondelegability rule narrowly serves the policy of compensation.

The second policy justification for the nondelegability rule is that it provides for more instances of plaintiff compensation than does the agency regime. ${ }^{161}$ The traditional agency approach would leave plaintiffs' harms uncompensated when agents acting without authority are judgment proof. ${ }^{162}$ Unlike the traditional agency analysis, the nondelegability rule provides for a greater chance of plaintiff compensation because it also prevents owners from shifting responsibility to agents acting without authority. ${ }^{163}$ By so doing, it ensures plaintiff compensation in the situation where the agent is unable to pay the damage award.

The particular features of the FHA, however, cast doubt on the conclusion that the nondelegability regime actually does create a significantly greater chance of plaintiff compensation. As noted, compensatory damages are relatively small under the FHA. ${ }^{164}$ Because of

158 See Sykes, 93 Yale L J at 1236 (cited in note 95) (noting that a principal's assumption of an agent's liability "may lead to smaller investments by the agent in efforts to avoid judgments").

159 See Walker, 976 F2d at 905 n 9 ("[T] he owner will not be subject to liability for the full amount of all successful claims to the extent that contribution from other liable parties may offset some, or all, of the payment for which the owner is responsible.").

160 It is, of course, possible that other factors will contribute to the agent's willingness to discriminate, namely, the possibility of facing adverse employment actions and negative reputational effects as a result of the discrimination. Note, however, as in Walker and Matchmaker, agents often discriminate despite these results, even if the owner has specifically instructed them not to.

161 See Part II.B.3.b.

162 See Sykes, 93 Yale L J at 1242 (cited in note 94) ("[T]he choice between personal liability and vicarious liability will affect ... the allocation of losses between the principal-agent enterprise and the victim of the agent's wrongs.").

163 Id.

164 See note 153 and accompanying text. 
these small awards, the probability that the agent acting without authority will be unable to pay is greatly reduced. As one court has observed: "In the great majority of cases we may assume that real estate agents will not ... be judgment proof." ${ }^{165}$ If agents will be able to satisfy the compensatory award in the great majority of cases, the nondelegability rule does not materially advance the FHA's policy of compensation.

Undoubtedly, there is a theoretical class of aggrieved plaintiffs who will not receive compensatory damages under the Act as interpreted according to traditional agency principles who would be compensated under a nondelegability regime. This small benefit is offset, however, by the fact that under the nondelegability rule there may be less deterrence, a fact leading to more instances of discrimination. While the nondelegability rule will moderately serve the policy of compensation, it is only at the price of more discrimination. Because the policy of deterrence outweighs the policy of compensation, ${ }^{166}$ this is a high price indeed.

\section{CONCLUSION}

The continued imposition of a nondelegable duty under the FHA against owners is inadvisable. All of the interpretive sources counsel for an abandonment of the nondelegable duty approach. The text of the Act does not support the creation of a nondelegable duty. In addition, HUD's regulations counsel for the application of agency principles. Likewise, the precedent does not establish that the Act should be interpreted to impose a nondelegable duty. Finally, although the Act is to be interpreted broadly, the imposition of a nondelegable duty is too broad a measure considering its relationship to other civil rights statutes and the marginal benefits it offers.

165 Walker, $976 \mathrm{~F} 2 \mathrm{~d}$ at $905 \mathrm{n}$ 9. Interestingly, the court in Walker nevertheless applied the nondelegability rule. But according to the court's statement, the circuitous route of damages paid will increase the overall costs of the litigation without producing a significant benefit to either plaintiffs or the public.

166 See 42 USC $\$ 3601$; note 145. 